\title{
Critical Period for Weed Control in Leek (Allium porrum L.)
}

\author{
Nihat Tursun \\ Department of Plant Protection, University of Sütçü Imam, 46100, \\ Kahramanmaras, Turkey \\ Bekir Bükün \\ Department of Plant Protection, University of Harran, 63040, Sanllurfa, \\ Turkey
}

\author{
Sinan Can Karacan \\ Dönüs Export and Import Co., Mersin, Turkey
}

Mathieu Ngouajio ${ }^{1}$

Department of Horticulture, Michigan State University, 428 Plant and Soil Sciences, East Lansing, MI 48824

\section{Hüsrev Mennan \\ Department of Plant Protection, Ondokuz Mayis University, Samsun, Turkey}

Additional index words. integrated weed management, vegetables, weed competition yield loss

\begin{abstract}
Field studies were conducted in Mersin, Turkey, in 2002 and 2003 to determine the critical period for weed control in leek and to investigate the effects of weed interference on weed biomass. The critical period for weed control in leek based on a $5 \%$ acceptable yield loss level was calculated by fitting logistic and Gompertz equations to relative yield data. Total fresh biomass of weeds increased as the duration of weed infestation increased. The beginning of the critical period for weed control was 7 days after transplanting in 2002 and 13 days after transplanting in 2003. The end of the critical period for weed control was 85 days after transplanting in 2002 and 60 days after transplanting in 2003. Results of this study suggest that leek should be kept weed free between 7 days after transplanting and 85 days after transplanting to avoid yield losses in excess of $5 \%$.
\end{abstract}

Leek is a major vegetable crop worldwide. Most of its production and consumption is in western Europe, with France and Belgium being the world's greatest producers (De Clercq et al., 1999). In Turkey, $\approx 290,000$ tons of leek was produced in 2002 from an estimated 12,083 ha. Dry leek is the most consumed vegetable in Turkey after potato (Ermenli and Yoldaş, 1999).

Like many other vegetables, leek is a weak competitor against weeds, thus requiring high costs for weed management (Baumann et al., 2000). Growth and yield of leek are substantially reduced by weed competition for nutrients, water, and light. Yield reduction depends on multiple factors, including weed species, weed density, time of weed emergence relative to crop emergence, weed distribution, soil type, soil moisture, $\mathrm{pH}$, and soil fertility level.

In Turkey, there are currently no herbicides registered for leek. Cultivation and hand hoeing are the common practices used. These techniques are time-consuming and require considerable labor; therefore, they

Received for publication 18 June 2006. Accepted for publication 11 Sept. 2006.

${ }^{1}$ To whom reprint requests should be addressed; e-mail ngouajio@msu.edu are not usually cost-effective and appropriate (Ngouajio et al., 1997).

Environmental and health concerns and growing markets for high-value and ecologically produced vegetables have encouraged farmers to search for production techniques that could help reduce or eliminate synthetic herbicide use (Baumann et al., 2000). Integrated weed management (IWM) combines preventive and curative weed control methods, based on ecological principles, to address environmental and economic concerns. Under IWM, herbicides may be applied as corrective measures if other weed management tactics fail to protect a crop adequately. In organic farming, nonchemical methods are generally preferred and synthetic chemicals are not allowed. In organically grown crops with weak competitive ability, like onion, leek, and carrot, more than $400 \mathrm{~h} \cdot \mathrm{ha}^{-1}$ of hand weeding may be necessary to reach a level of weed control comparable with that obtained with herbicides (Vereijken and Kropff, 1996). Because labor-intensive methods of weed control are not sustainable, preventive strategies, decision-making tools, and improved control technologies have been suggested (Kropff et al., 1996).

With respect to improved decision making, application of the critical period thresh- old model (Nieto et al., 1968) has been suggested for reducing losses resulting from weeds in vegetable production systems (Roberts,1976; Zimdahl, 1988, 1993). By controlling weeds during the critical period, reductions in the yield and quality can be minimized (Müller-Schärer and Baumann, 1993).

The critical period for weed control is important for the development of alternative weed management strategies (Swanton and Weise, 1991). It allows identification of appropriate timing for weed management and aids in understanding the affect of weed populations on crop yield. Research on the critical period for weed control is usually performed by measuring the affect of earlyseason weed competition and late-season weed competition (Nieto et al., 1968). Early-season weed competition is achieved by allowing weeds to emerge and grow with the crop for certain predetermined times, after which all weeds are removed in a timely manner until harvest. For late-season weed competition, the crop is kept free from weeds until certain predetermined times, after which weeds are allowed to emerge and compete with the crop for the remainder of the growing season.

Many studies have been conducted to determine the critical period for weed control in various crops under various environmental conditions (Bryson, 1990; Buchanan et al., 1980; Dawson, 1970; Evans et al., 2003; Knezevic et al., 2003; Rogers and Buchanan, 1986; Van Acker et al., 1993). However, there are limited published studies on the critical period for weed control in vegetables in general and leek in particular (Amador-Ramirez, 2002; Baumann et al., 2000; Buckelew et al., 2006; Tursun et al., 2004; Weaver, 1984). Because of the differences in climatic conditions and weed populations, result of studies conducted in different environments or on different crops may not apply to other systems (Bukun, 2004; Evans et al., 2003; Knezevic et al., 2003; Van Acker et al., 1993). The critical period for weed control in leek has not been determined in many regions, including Turkey. This information could help leek producers improve the efficacy of their current weed management systems and reduce yield loss resulting from weed competition. The objectives of this study were, therefore, to determine the critical period for weed control in leek under conditions found in Turkey and to investigate the effect of weed interference on leek yield.

\section{Materials and Methods}

Site description. Experiments were conducted at the experimental farm of Dönüs Export and Import Co. located in the Mediterranean region of Turkey (lat. $36^{\circ} 48^{\prime} \mathrm{N}$ and long. $34^{\circ} 38^{\prime} \mathrm{E}$ ) in Mersin province during the 2002 and 2003 growing seasons. The soil was a vertisol with $54 \%$ clay, $18 \%$ silt, $21 \%$ sand, a $\mathrm{pH}$ of 7.7 , and $0.4 \%$ organic matter. 
Experimental design. Soil preparation was conducted according to local practices for leek production. The soil was chisel plowed, followed by a disk harrow, and finally by a harrow to obtain a smooth seedbed. Leek cultivar Kartal was sown on 5 June 2002 and 2003. The seed was broadcast on the seedbed and incorporation into the soil. The soil surface was then covered with wood shavings to retain soil moisture and the seedlings were irrigated as necessary. Seedlings were transplanted on 19 Sept. 2002 and 2003 with a 30-cm spacing between rows and $10 \mathrm{~cm}$ between plants inside the row. Before transplanting, $90 \mathrm{~kg} \cdot \mathrm{ha}^{-1} \mathrm{~N}, 90 \mathrm{~kg} \cdot \mathrm{ha}^{-1} \mathrm{P}_{2} \mathrm{O}_{5}$, and $90 \mathrm{~kg} \cdot \mathrm{ha}^{-1} \mathrm{~K}_{2} \mathrm{O}$ were applied to the field. When leek reached $60 \mathrm{~cm}, 100 \mathrm{~kg} \cdot \mathrm{ha}^{-1} \mathrm{~N}$ was applied. The field was irrigated after transplanting to improve transplant establishment. Natural rainfall was enough to meet plant water requirements during the remainder of the growing seasons. Leek plants were harvested on 18 Feb. 2003 and 26 Feb. 2004.

The experimental design was a randomized complete block with four replications. Two types of weed interference treatments were implemented after transplanting. The first treatment regime was intended to determine the beginning of the critical period of weed removal. Weeds competed with leek for $0,10,20,30,40,50$, and $60 \mathrm{~d}$ after transplanting (DAT). The goal of the second set of treatments was to determine the end of the critical period. Plots were kept weed free for $0,10,20,30,40,50$, and 60 DAT by periodic hand hoeing. A weed control treatment was maintained in each component until leek harvest. Each plot consisted of 12 leek rows spaced $30 \mathrm{~cm}$ apart and was 2.5 $\mathrm{m}$ long. The two outer rows of each plot were used as buffer rows and 10 middle rows were used for weed biomass and yield assessments.

Weed and crop measurement. Experiments were conducted on different sites within the location during successive years. Naturally occurring weed populations were used in both trials.

Weed infestations were evaluated at the completion of each treatment by classifying and counting weed numbers in a $2 \times 1-\mathrm{m}$ quadrat/plot. Weeds were clipped at the soil surface inside a $1 \times 1-\mathrm{m}$ quadrat to determine above-ground fresh biomass. Leek was hand harvested at full maturity in the 2-m middle section of the 10 middle rows.

Meteorological data. Weather data during the growing seasons were obtained from Turkish State Mersin Meteorological Service as mean daily temperature and total monthly rainfall (Table 1).

Statistical analysis. The relationship between duration of weed interference and weed biomass was described using PROC NLMIXED in SAS (SAS Institute, 1999). The relationship between weed biomass and the duration of early-season weed-free period was described using the following modified logistic model (Sit and Costello, 1994):

Table 1. Mean daily temperature and total monthly rainfall from Feb. to Dec. in 2002 and 2003 at the experimental locations.

\begin{tabular}{lccrrr}
\hline & \multicolumn{2}{c}{ Temperature $\left({ }^{\circ} \mathrm{C}\right)$} & & \multicolumn{2}{c}{ Precipitation $(\mathrm{mm})$} \\
\cline { 2 - 3 } \cline { 5 - 6 } Month & 2002 & 2003 & & 2002 & 38 \\
\hline Jan. & 10 & 13 & 102 & 116 \\
Feb. & 14 & 13 & 81 & 95 \\
Mar. & 16 & 18 & 75 & 46 \\
Apr. & 17 & 24 & 16 & 2 \\
May & 22 & 26 & 8 & 16 \\
June & 26 & 29 & 6 & 10 \\
July & 29 & 30 & & 0 & 0 \\
Aug. & 29 & 26 & 69 & 5 \\
Sept. & 26 & 23 & 61 & 36 \\
Oct. & 23 & 17 & 70 & 90 \\
Nov. & 18 & 10 & - & -15 \\
Dec. & 11 & 20 & 526 & 458 \\
Average & 20 & - & &
\end{tabular}

$$
W B=\frac{a}{(1+b \times \exp (-c \times t))}
$$

where, $W B$ is the weed fresh biomass (measured in kilograms/hectare), $a$ is the $Y$-intercept, $b$ and $c$ are constants, and $t$ is the length of the weed-free period.

A slightly modified Gompertz model as described by Sit and Costello (1994) was used to describe the relation between weed biomass and increasing duration of weed interference:

$$
W B=g \times \exp [-\exp (h-i \times t)]
$$

where, $W B$ is the weed fresh biomass (measured in kilograms/hectare), $g$ is the maximum weed biomass, $h$ and $i$ are constants, and $t$ is the duration of the period of weed infestation.

Relative yield data were subjected to analysis of variance using PROC NLMIXED in SAS (SAS Institute, 1999). Relative yield of each treatment was calculated by dividing the yield of the treatment by the weed-free yield and expressing the result as a percentage. The significance of interaction between year and treatment combinations was evaluated at the $P=0.05$ level.

Mixed-model nonlinear regression analysis using PROC NLMIXED in SAS (SAS Institute, 1999) was used to model relative yield as a function of the duration of weed interference or length of the weed-free period, according to the procedure outlined by Knezevic et al. (2002)

A three-parameter logistic equation proposed by Hall et al. (1992) and modified by Knezevic et al. (2003) was used to describe the effect of increasing duration of weed interference on relative yield and to determine the onset of the critical period. The equation had the following form:

$$
\begin{aligned}
Y= & {\left[\frac{1}{\exp (C \times(T-D))+F}+\frac{F-1}{F}\right] } \\
& \times 100
\end{aligned}
$$

where, $Y$ is the relative yield (measured as a percentage of the season-long weed-free yield), $T$ is the duration of weed interference measured from the time of transplanting in days, $D$ is the point of inflection, $C$ and $F$ are constants.

The Gompertz model has been shown to provide adequate fit to yield under increasing length of weed-free period (Hall et al., 1992; Knezevic et al., 2002). The model has the following form:

$$
Y=A \times \exp [-B \times \exp (-K \times T)]
$$

where $Y$ is the relative yield (measured as a percentage of the season-long weed-free yield), $A$ is the relative yield asymptote, $B$ and $K$ are constants, and $T$ is the length of the weed-free period after crop planting in days.

The critical period for weed control was determined using arbitrary yield loss levels of $2.5 \%, 5 \%$, and $10 \%$. However, the $5 \%$ yield loss level was used for detailed discussion of the results.

\section{Results}

Weed measurements. The most prominent weeds in the experimental plot were Brassica kaber (DC.) Wheeler, Convolvulus arvensis L., Cyperus rotundus L., Portulaca oleracea L., Chenopodium album L., Datura stramonium L., Sorghum halepense (L.) Pers., Cirsium arvense (L.) Scop., and Amaranthus retroflexus L. (Table 2 ). Weed density measured at 150 DAT was 120 plants $/ \mathrm{m}^{2}$ and 148 plants $/ \mathrm{m}^{2}$ in 2002 and 2003 respectively. Differences in the weed community between years were minor and could be the result of the use of different experimental sites and management practices in previous crops.

Total fresh biomass of weeds increased as the duration of weed infestation increased (Fig. 1). C. arvense, B. kaber, and S. halepense contributed most of the total weed fresh biomass because of their large size and density. Total weed fresh biomass in both growing seasons decreased with increasing duration of the weed-free period and there were no statistical differences between years (Table 2). Data on weed biomass from increasing weed-free or weed interference treatments adequately fit the Gompertz and logistic models (Fig. 1). Values of coefficient of determination $\left(R^{2}\right)$ of the regression were more than 0.97 in all cases. 
Table 2. Weed composition and average density in a weed plot measured $150 \mathrm{~d}$ after leek planting in 2002 and 2003 .

\begin{tabular}{llrr}
\hline & & \multicolumn{2}{c}{ Density $\left(\mathrm{plants} / \mathrm{m}^{-2}\right)$} \\
\cline { 2 - 4 } Common Name & \multicolumn{1}{c}{ Scientific Name } & 2002 & 2003 \\
\hline Redroot pigweed & Amaranthus retroflexus L. & 0.0 \\
Common lambsquarters & Chenopodium album L. & 1.3 & 1.0 \\
Canada thistle & Cirsium arvense (L.) Scop. & 3.0 & 2.3 \\
Field bindweed & Convolvulus arvensis L. & 1.7 & 24.0 \\
Purple nutsedge & Cyperus rotundus L. & 14.0 & 34.0 \\
Jimsonweed & Datura stramonium L. & 2.0 & 2.0 \\
Common purslane & Portulaca oleracea L. & 5.3 & 7.9 \\
Wild mustard & Brassica kaber (DC.) Wheeler & 63.3 & 73.9 \\
Johnsongrass & Sorghum halepense (L.) Pers. & 1.3 & 2.6 \\
Total & & 120 & 148 \\
\hline
\end{tabular}

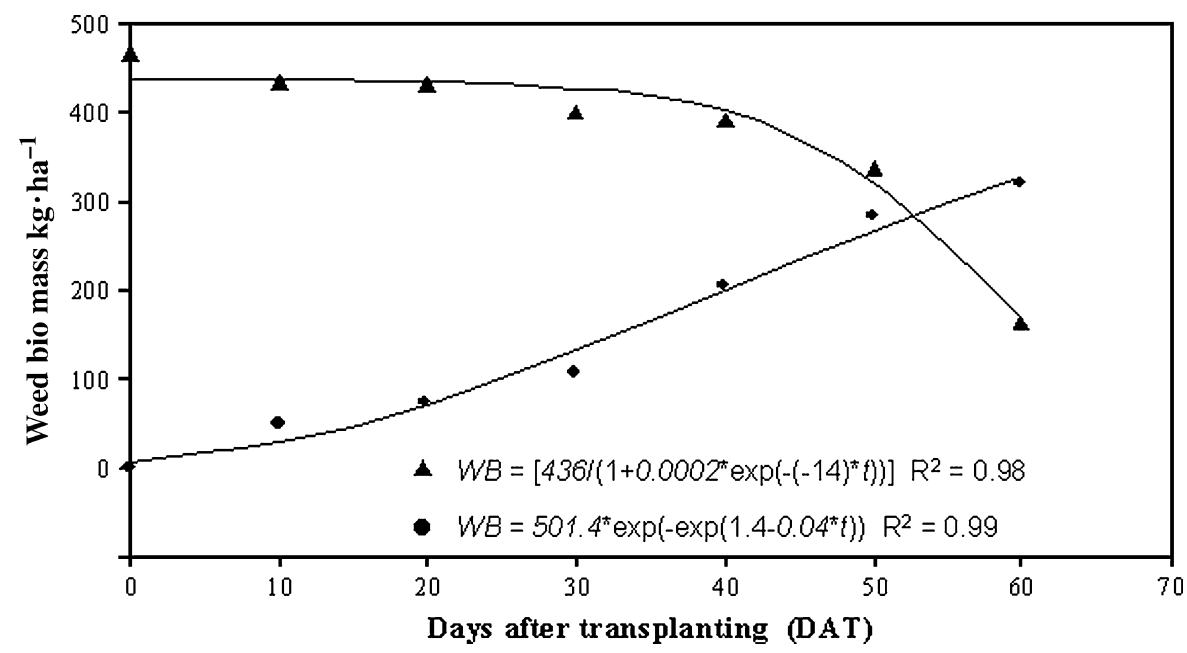

Fig. 1. Effects of increasing duration of weed interference $(\bullet)$ and weed-free $(\boldsymbol{\Delta})$ period on weed fresh biomass accumulation in leek production. The symbols and the lines represent observed and predicted weed fresh biomass, respectively. Data were combined for the 2002 and 2003 seasons because of the lack of a significant difference between years.

Yield response and critical period of weed control. Because a significant interaction between years and treatments was observed $(P<0.001)$, data were analyzed separately for both years. Parameters for the logistic and Gompertz equations were obtained for each year (Fig. 2.). Likewise, the onset and the end of the critical period for weed control were calculated by year. Predicted and observed relative leek yield as affected by duration of the weed-infested or weed-free period are shown in Fig. 2. The responses were strong (as identified by the high $R^{2}$ values) in both years.

The onset of critical period in leek became earlier as the predetermined acceptable yield loss level (AYL) decreased from 10\% to $2.5 \%$ (Fig. 2). At $2.5 \%$ AYL, the beginning of the critical period for weed control was negative in 2002. The beginning of the critical period for weed control occurred at 7 DAT in 2002 and 13 DAT in 2003, at 5\% AYL. The end of the critical period for weed control was 85 DAT in 2002 and 60 DAT in 2003 , at 5\% AYL. The end of the critical period for weed control increased as the AYL decreased from $10 \%$ to $2.5 \%$ (Fig. 2). The differences between the beginning and the end of the critical period for weed control in both years were probably the result of the difference in weed densities between the growing seasons (Table 2).

\section{Discussion}

Results of the experiments showed that yield of leek declined with increasing duration of weed presence and this response was in agreement with previous findings reported on other crops (Amador-Ramirez, 2002; Bukun, 2004; Hall et al., 1992; Medina, 1995; Ngouajio et al., 1997; Van Acker et al., 1993).

A significant reduction in leek yield may $C$. arvensis, $C$. rotundus, $P$. oleracea, $C$. album, D. stramonium, $S$. halepense, $C$. arvense, and $A$. retroflexus. During the first 1.5 to 4.5 weeks of the experiments (roughly 7-28 DAT), these weeds overshadowed or covered the soil surface and competed with leek for light, water, and minerals. This competition effect presumably resulted in a reduction in photosynthesis, which slowed the growth and biomass accumulation rate and caused poor leek growth. In temperate climates, many vegetables (including species in the Liliaceae family, carrots, and peppers) have a slow growth rate and cover the soil very sparsely, which results in strong weed competition (Zaragoza, 2003). be explained by interference from $B$. kaber,
The beginning of the critical period for weed control in leek was 7 DAT and 13 DAT, and the end of the critical period for weed control was 85 DAT and 60 DAT using a 5\% AYL in 2002 and 2003 respectively (Fig. 2). The onset of the critical period for weed control was earlier in 2002 compared with 2003. This early onset could be attributed to greater rainfall in 2002, especially during the month of May, that preceded leek transplanting (Table 1). Based on the weed density, the critical period for weed control was expected to be earlier in 2003 (with high weed density) than in 2002. However, the reverse was observed, suggesting a possible competition among weeds under high density. These findings agree with previous results from other researchers on different crops (Bukun, 2004). The beginning of the critical period for weed control defined in the classical sense (Nieto et al., 1968) could not be determined for the $2.5 \%$ AYL in 2002, for which the onset of the critical period for weed control was negative. This means that at this weed density and with these species, a $2.5 \%$ leek yield reduction could not be determined.

If weed control in leek is not carried out in a timely manner, there will be no production at all. There are many examples of problems in crop yield reduction that indicate the great susceptibility of vegetables to early weed competition and the need to control weeds at early crop stages (Labrada, 1996).

Results were consistent with previous results on the critical period for weed control in various vegetable crops. In Switzerland, Baumann et al. (2000) reported that the critical period for weed control in pure-stand leek crops was $52 \mathrm{~d}$ after crop establishment. In this study, the duration of the critical period for weed control in leek was 78 d and 58 d in 2002 and 2003 respectively. The difference between the two studies and within years in this study could be attributed mainly to different weed densities and species, as well as to environmental factors. Some traditional techniques are thought to increase crop competitiveness (e.g., transplant, earthing up). Weather conditions and weed density have a great influence on the length of critical periods. A cold wave affecting spring vegetables can cause slow growth, higher susceptibility to competition, and greater yield loss (Zaragoza, 2003).

Because of increased emphasis on longterm management of weed populations in cropping systems with reduced reliance on herbicides, the production of seeds by weeds that emerge after the critical period for weed control can affect weed populations in subsequent seasons. Therefore, long-term weed management should also prevent weeds that emerge outside the critical period for weed control from setting seeds.

The development of an IWM requires knowledge about the behavior of weeds in agro-ecosystems, including possible effects on crop yield (Amador-Ramirez, 2002). The critical period for weed control is a key component of IWM strategies, and the results of this experiment contribute to the development 


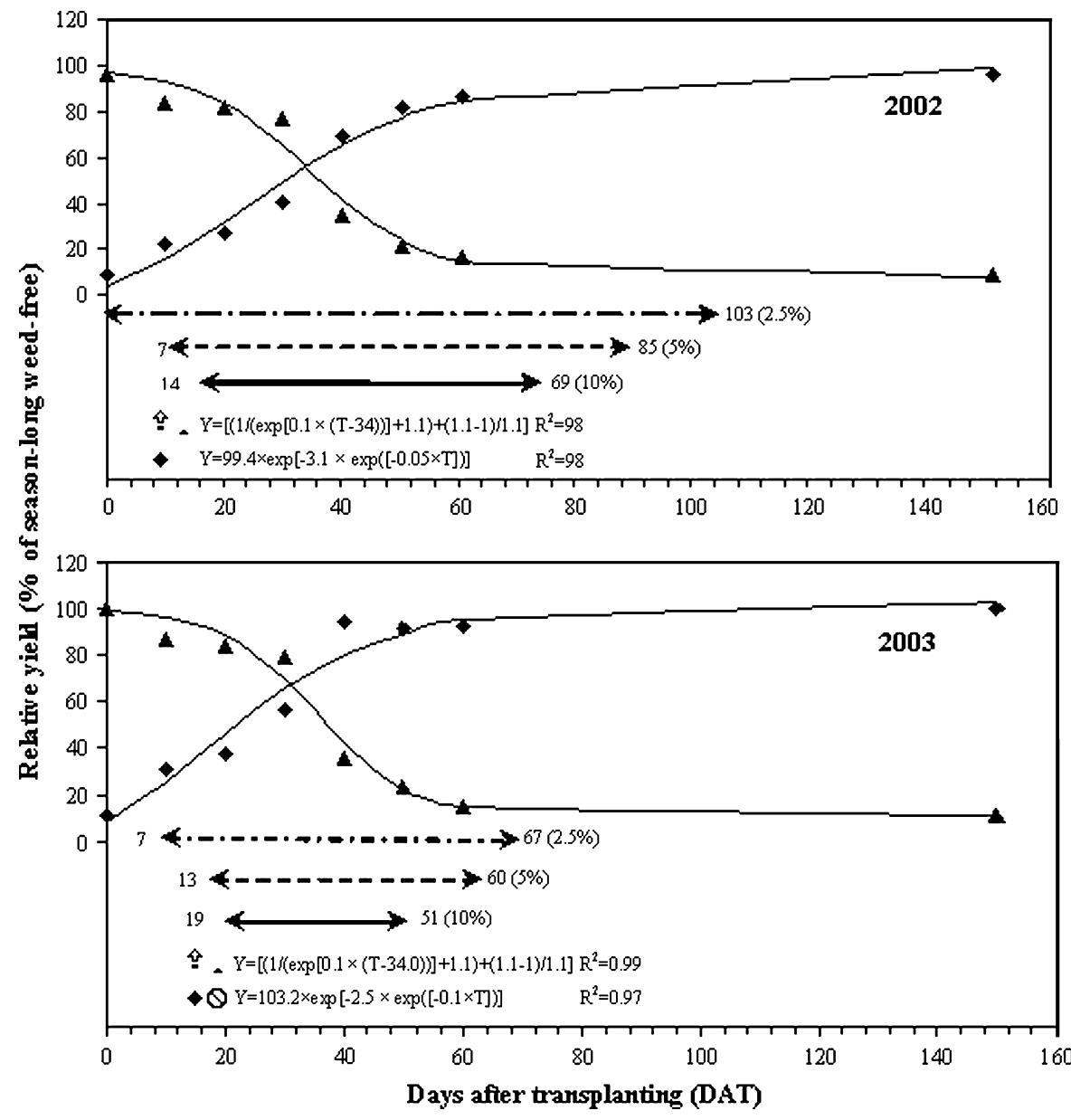

Fig. 2. Effect of weed interference on leek relative yield. Increasing duration of weed interference $(\boldsymbol{\Delta})$ data fit the logistic equation; the increasing weed-free period ( $\bullet$ ) data fit the Gompertz equation. The symbols and the lines represent observed relative yield and predicted relative yield respectively. Horizontal lines represent the beginning and the end of the critical period in days after transplanting at $2.5 \%, 5 \%$, and $10 \%$ yield loss levels. The beginning of the critical period for weed control for the $2.5 \%$ yield loss level was negative in 2002 .

of such a system for leek growers in Turkey and other major leek production regions like France and Belgium with a similar climate and weed composition. Data from this study provide a basis for leek producers to make a decision with respect to timely weed control measures. The practical implication of this study is that weeds must be controlled from 7 to 85 DAT of leek to prevent appreciable economic yield loss.

\section{Literature Cited}

Amador-Ramirez, M.D. 2002. Critical period of weed control in transplanted chili pepper. Weed Res. 42:203-209.

Baumann, D.T., M.J. Kropff, and L. Bastiaans. 2000. Intercropping leeks to suppress weeds. Weed Res. 40:359-374.

Bryson, C.T. 1990. Interference and critical time of removal of hemp Sesbania (Sesbania exeltata) in cotton (Gossypium hirsutum). Weed Technol. 4:833-837.

Buchanan, G.A., R.H. Crowley, J.E. Street, and J.A. McGuire,. 1980. Competition of sicklepod (Cassia obtusifolia) and redroot pigweed (Amaranthus retroflexus) with cotton (Gossypium hirsutum). Weed Sci. 28:258-262.
Buckelew, J.K., D.W. Monks, K.M. Jennings, G.D. Hoyt, and R.F. Walls. 2006. Eastern black nightshade (Solanum ptycanthum) reproduction and interference in transplanted plasticulture tomato. Weed Sci. 54:490-495.

Bukun, B. 2004. Critical periods for weed control in cotton in Turkey. Weed Res. 44:404-412.

Dawson, J.W. 1970. Time and duration of weed infestations in relation to weed-crop competition. Proc. South. Weed Sci. Soc. 23:13-15.

De Clercq, H., J. Baert, and E. Van Bockstaele. 1999. Breeding potential of Belgian landraces of leek (Allium ampeloprasum L. var. porrum). Euphytica. 106:101-109.

Ermenli, B. and T. Yoldaş. 1999. Bazı pırasa çeşit ve hatlartnın derin dondurmaya uygunlukları üzerine bir araştırma, p. 269-278. Ulusal Bahçe Bitkileri Kongresi, Adana, Turkey.

Evans, S.P., S.Z. Knezevic, J.L. Lindquist, C.A. Shapiro, and E.E. Blankenship. 2003. Nitrogen application influences the critical period for weed control in corn. Weed Sci. 51:408-417. 1992. The critical period of weed control in grain corn (Zea mays). Weed Sci. 40: $441-447$.

Knezevic, S.Z., S.P. Evans, E.E. Blankenship, R.C. Van Acker, and J.L. Lindquist. 2002. Critical
Hall, M.R., C.J. Swanton, and G.W. Anderson. period for weed control: The concept and data analysis. Weed Sci. 50:773-786.

Knezevic, S.Z., S.P. Evans, and M. Mainz. 2003. Row spacing influences the critical timing for weed removal in soybean (Glycine Max). Weed Technol. 17:666-673.

Kropff, M.J., J. Wallinga, and L.A.P. Lotz. 1996. Weed population dynamics, p. 3-14. In: Brown, H. et al. (eds). Proceedings of Second International Weed Control Congress. DIAS Slagelse, Denmark

Labrada, R. 1996. Manejo de malezas en hortalizas, p. 298-308. In: R. Labrada, J.C. Caseley, and C. Parker (eds.). Manejo de malezas para países en desarrollo. Estudio FAO Producción y Protección Vegetal 120. FAO, Rome, Italy.

Medina, A. 1995. Estudio de la flora arvense y su competencia en los cultivos de transplante y siembra directa de pimiento (Capsicum annuum L.). Escuela T.S. de Ingeniería Agraria. Univ. de Lérida, Spain. PhD Diss.

Müller-Schärer, H. and D.T. Baumann. 1993. Unkrautregulierung im Gemüsebau: Konzepte zur Reduktion des Herbizideinsatzes. Landwirtschaft Schweiz. 6:401-412.

Ngouajio, M., J. Foko, and D. Fouejio. 1997. The critical period of weed control in common bean (Phaseolus vulgaris L.) in Cameroon. Crop Prot. 16:127-133.

Nieto, H.J., M.A. Brondo, and J.T. Gonzales. 1968. Critical period of crop growth cycles for competition from weeds. Pest Artic. News Summ. (C). 14:159-166.

Roberts, H.A. 1976. Weed competition in vegetable crops. Ann. Appl. Biol. 83:321-324.

Rogers, N.K. and G.A. Buchanan. 1986. Influence of row spacing on weed competition with cotton. Weed Sci. 24:410-414.

SAS Institute. 1999. SAS systems. Version 8. Statistical Analysis Systems Institute, Cary, N.C.

Sit, V. and M.P. Costello. 1994. Catalog of curves for curve fitting. Biometrics information handbook series. Ministry of Forests, Victoria, B.C. Canada.

Swanton, C.J. and S.F. Weise. 1991. Integrated weed management: The rationale and approach. Weed Technol. 5:657-663.

Tursun, N., S.C. Karacan, A.O. Tursun, and H. Bilir. 2004. Effects of weed competition periods on the yield of leek. Plant Dis. Prot. 19:309-311.

Van Acker, R.C., C.J. Swanton, and S. Weise 1993. The critical period of weed control in soybean (Glycine max (L.) Merr.). Weed Sci. 41:194-200.

Vereijken, P. and M.J. Kropff. 1996. Prototyping ecological farming systems. Annual report of the DLO Research Institute for Agrobiology and Soil Fertility, p. 56-60. Wageningen, the Netherlands.

Weaver, S.E. 1984. Critical period of weed competition in 3 vegetable crops in relation to management practices. Weed Res. 24:317-325.

Zaragoza, C. 2003. Weed management in vegetables. Weed management for developing countries FAO plant production and protection paper 120 addendum 1. 9 Sept. 2006 $<$ www.fao.org/docrep/006/Y $5031 \mathrm{E} /$ y5031e 0 b.htm>

Zimdahl, R.L. 1988. The concept and application of the critical weed-free period, p. 145-155. In: M.A. Altieri, and M. Leibman (eds.). Weed management in agro-ecosystems: Ecological approaches CRC Press, Boca Raton, Fla.

Zimdahl, R.L. 1993. Fundamentals of weed science. Academic, San Diego, Calif 